\title{
Retrospective comparison of the efficiency of sperm preparation methods in intrauterine insemination in unexplained infertility
}

\author{
Açıklanamayan İnfertilite Olgularında Uygulanan İntrauterin İnseminasyonlarda Sperm Hazırlama \\ Yöntemlerinin Etkinliklerinin Geriye Dönük Karşılaştırılması
}

Asli Yaylali ${ }^{1 *}$

1.Kahramanmaras Sutcu Imam University, Faculty of Medicine, Department of Histology and Embryology, Kabramanmaras, Turkey

\begin{abstract}
Aim: To compare the effects on pregnancy rates of the sperm preparation methods used in intrauterine insemination (IUI) treatment in couples diagnosed with unexplained infertility.

Method: The study included 112 couples who presented at the Assisted Reproductive Techniques Clinic with no gynaecological problem observed in the female and semen analysis in the male showing features suitable for insemination, who were then diagnosed with unexplained infertility. The patients were evaluated in three groups according to the sperm preparation methods as Group 1 (Swim-Up), Group II (Gradient) and Group III (Microchip). The results were analyzed statistically and discussed in light of the relevant literature.

Results: No statistically significant difference was determined between the groups in respect to the age of the couples, duration of infertility, female basal FSH values, number of dominant follicles formed with ovulation induction, endometrium thickness during IUI, total number of motile sperm before sperm preparation, ratio of sperm with normal morphology (Kruger), motility rate after sperm preparation, and number of inseminated sperm ( $p>0.05$ for all). The mean number of IUI attempts was 3.68 in the Microchip group, 1.86 in the Swim-Up group and 1.82 in the Gradient group. A statistically significantly higher number of IUI attempts was made in the Microchip group than in the other groups $(p<0.01)$. In the comparison of the pregnancy rates, the highest rate of $22.73 \%$ was determined in the Microchip group, followed by $17.39 \%$ in the Gradient group and $15.91 \%$ in the Swim-Up group, with no statistically significant difference determined between the groups $(p=0.064)$.

Conclusion: Although there was no apparent difference in success between the two methods most frequently used in sperm preparation in IUI cycles (Swim-Up, Gradient), the method of sperm selection with Microchip, which is being increasingly used, seems to be a promising alternative. There is a need for further, prospective, randomized studies with a greater number of cases and which include the pregnancy outcomes.
\end{abstract}

Key Words: Infertility, IUI, microchip

\section{öz}

Amaç: Açıklanamayan infertilite tanısı almış çiftlerde, intrauterin inseminasyon (iUi) tedavisi için kullanılan sperm hazırlama yöntemlerinin gebelik oranları üzerine etkilerinin karşılaştırılması.

Yöntemler: Çocuk istemi nedeniyle tüp bebek merkezi'ne başvurmuş, kadında herhangi bir jinekolojik problem gözlenmemiş, erkekte semen analizi aşılama için uygun özelliklerde olan ve açıklanamayan infertilite tanısı alan 112 çift çalışmaya dahil edilmiştir. Hastalar sperm hazırlama yöntemlerine göre Grup I (Swim-Up), Grup II (Gradient), Grup III (Mikroçip) olmak üzere üç grupta değerlendirilmiştir. Sonuçlar istatistiksel olarak analiz edilip literatür eşliğinde tartışılmıştır.

Bulgular: Çalışmaya dahil edilen çiftlerin yaşları, infertilite süreleri, kadınların bazal FSH değerleri, ovulasyon indüksiyonu ile oluşan dominant folikül sayısı, IUI esnasındaki endometrium kalınlığı, sperm hazırlama öncesi total motil sperm sayısı, normal morfolojili (Kruger) sperm oranı, sperm hazırlama sonrası motilite oranı ve insemine edilen sperm sayıları arasında istatistiksel bir fark izlenmemiştir (Tüm p değerleri>0,05). Hastaların IUI deneme sayısı Mikroçip grubunda 3,68 bulunmuş iken Swim-Up grubunda 1,86 ve Gradiyent grubunda 1,82 olarak tespit edildi. Mikroçip grubundaki daha fazla iUi deneme sayısı diğer gruplara göre istatistiksel olarak yüksek bulundu $(p<0,01)$. Gebelik oranları karşılaştırıldığında ise en yüksek oran \%22,73 ile Mikroçip grubunda tespit edilirken (Swim-Up grubunda \%15,91, Gradient Grubunda \%17,39) arada istatistiksel olarak anlamlı fark görülmemiştir ( $p=$ 0,064).

Sonuç: IUI sikluslarında sperm hazırlamada en sık kullanılan iki method (SwimUp, Gradient) arasında bariz bir başarı farklılığı olmamakla bereber, günümüzde kullanımı gittikçe artış gösteren Mikroçip ile sperm seçme yöntemi umut verici bir alternatif olarak görülmektedir. Bu konuda daha fazla vaka sayısı ile birlikte, gebelik sonuçlarının da dahil edildiği prospektif randomize çalışmalara intiyaç vardır.

Received: 20.12.2019 Accepted: 06.03.2020 Published (Online): 12.07.2020

*Corresponding author: Yaylali A., Kahramanmaras Sutcu Imam University, Faculty of Medicine, Department of

Histology and Embryology, Kahramanmaras, Turkey. Phone: +905057070377 e-mail: aslierylmz@gmail.com

ORCID: 0000-0003-2360-5320

To cited: Yaylali A. Retrospective comparison of the efficiency of sperm preparation methods in intrauterine insemination in unexplained infertility cases. Acta Med. Alanya 2020;4(2):132-136. doi:10.30565/medalanya.661870 


\section{INTRODUCTION}

ntrauterine insemination (IUI) is a method used in the treatment of couples with long-term infertility. For couples with unexplained infertility who are to undergo in vitro fertilization treatment, the female follicles are first stimulated with different protocols before the male semen sample treated with various washing methods is administered to the female [1].

There are several methods that have been used for many years for the preparation of the sperm sample, of which the most commonly used are the Gradient and the Swim-Up methods. Although several studies have compared the effect of washing methods on pregnancy success, there is insufficient evidence of which method is more successful in increasing pregnancy [2-5]. Microfluid systems are technology products formed from microchannels a few hundred micrometers in length which are used to differentiate small amounts of fluid and the particles within the fluid. These systems are a new method used in recent years in both IVF and IUI and have come into use with claims of the selection of sperm occurring with Iow DNA damage. The best known of these, which is used in our clinic, is the microchip method [6] which has come to the fore as an alternative sperm selection method usually applied to patients who have undergone IUI several times, but have not become pregnant. Although there are studies in the literature which have compared the success of this method with standard sperm selection methods in IVF cycles [7], there is limited data available in the literature related to IUI successes.

The aim of this study was to retrospectively show the effects on laboratory test results and pregnancy success in cases with unexplained fertility of sperm samples prepared with Gradient, Swim-Up and Microchip methods in couples diagnosed with unexplained infertility.

\section{METHODS}

Approval for the study was granted by the Clinical Research Ethics Committee of Kahramanmaraş Sütçü Imam University (decision no: 02, session: 2019/15). The study included 112 patients who had presented at the Assisted Reproductive Techniques Center of Kahramanmaraş Sütcu
Imam University between January 2016 and August 2018 because of their wish to conceive. The patients included had infertility ongoing for at least 1 year and were found to be suitable for IUI treatment with at least one tube open on hysterosalpingography (HSG), progressively motile sperm count of at least 10 million and/or a diagnosis of unexplained infertility. These 112 patients were separated into 3 groups according to the sperm preparation method:

Group I (Swim-Up) (n:44): The semen sample taken on the day of IUI was applied with the SwimUp washing procedure to obtain high-quality sperm to be applied in IUI.

Group II (Gradient) (n:46): The semen sample was applied with the Gradient technique then IUI was applied after washing.

Group III (Microchip) (n:22): Sperm selection was made from the sperm sample using the Microchip method, then IUI was applied.

In the investigation of infertility etiology, transvaginal ultrasonography was performed on the $2 \mathrm{nd}$ or $3 \mathrm{rd}$ day of the cycle, and measurements were taken of follicle stimulating hormone (FSH), luteinizing hormone (LH) and estradiol (E2). The couples included in the study had no chronic disease and were not using any drugs other than those in the IUI treatment.

The females in each couple were evaluated in respect of age, duration of infertility, gravida, abortus and parity, and the males were evaluated in respect of age and semen parameters. The demographic data and laboratory test results were recorded.

The females of the couples included in the study took Letrozole $2.5 \mathrm{mg}$ (Femara, Novartis, Switzerland) twice a day for 5 days, starting on the 3rd or 5th day of the menstrual cycle, and were applied with ultrasound on the 3rd day after finishing the drug course. In patients where sufficient follicular development was not observed, a daily recombinant FSH (Gonal F, Merck Sereno, Modugno, Italy) injection was started. In the follicle follow-up measurements applied with ultrasound, on the day one of the follicles was seen to be $>17 \mathrm{~mm}, 6500$ units recombinant human chorionic 
gonadotropin (Ovitrelle, Merck Sereno, Modugno, Italy) was administered followed by the IUI procedure 36-48 hours later.

When preparing the semen samples for IUI, the sperm concentration, sperm count per $\mathrm{ml}$, and total progressively motile sperm count were evaluated under contrast light microscope (Olympus CX41) before and after washing, and all the data were recorded. Positive beta HCG results at 14 days after the IUI procedure, and the outcomes of continued clinical pregnancy were recorded from a scan of the files.

Statistical analysis: Data obtained in the study were analyzed statistically using IBM SPSS for Windows, version 22.0 software (IBM statistics for Windows version 22, IBM Corporation, Armonk, NY, USA). Data were stated as mean \pm standard deviation (SD) values. Variance analysis (Repeated measures ANOVA with Bonferroni correction) was applied to repeated measurements. In the comparison of paired groups, the Tukey HSD was used. A value of $p<0.05$ was accepted as statistically significant.

\section{RESULTS}

No statistically significant difference was determined between the cases in respect of female age, male age, duration of infertility, basal FSH values, dominant follicle count formed with ovulation induction, endometrium thickness during IUI, total motile sperm count and normal morphology (Kruger) before preparation, and number of sperm inseminated after preparation ( $p>0.05$ for all) (Table 1). The number of IUI attempts was determined as 3.68 in the Microchip group, 1.86 in the Swim-Up group and 1.82 in the Gradient group (Table 1). The elevation in the microchip group was statistically significantly higher than the other groups $(p<0.01)$. When the pregnancy rates were compared, the highest rate was determined in the Microchip group at $22.73 \%$ and the difference between the groups was not statistically significant, with $15.91 \%$ in the SwimUp group and $17.39 \%$ in the Gradient group $(p=0.064)($ Table 2, Figure 1).
Table 1. Demographic characteristics of the cases.

\begin{tabular}{|l|l|l|l|l|}
\hline & $\begin{array}{l}\text { Swim-Up } \\
\text { Group }(\mathrm{n}: 44)\end{array}$ & $\begin{array}{l}\text { Gradient } \\
\text { Group (n: 46) }\end{array}$ & $\begin{array}{l}\text { Microchip } \\
\text { Group (n: 22) }\end{array}$ & $\mathrm{P}$ \\
\hline $\begin{array}{l}\text { Female age } \\
\text { (years) }\end{array}$ & $\begin{array}{l}28.43(\min \\
21-\max 35)\end{array}$ & $\begin{array}{l}27.93(\min 20- \\
\max 36)\end{array}$ & $\begin{array}{l}28.31(\min \\
21-\max 35)\end{array}$ & 0.789 \\
\hline $\begin{array}{l}\text { Male age } \\
\text { (years) }\end{array}$ & $\begin{array}{l}29.20(\min \\
23-\operatorname{max~38)}\end{array}$ & $\begin{array}{l}29.828(\min 24 \\
-\max 39)\end{array}$ & $\begin{array}{l}30.19(\min \\
22-\max 38)\end{array}$ & 0.859 \\
\hline $\begin{array}{l}\text { Duration of } \\
\text { infertility } \\
\text { (years) }\end{array}$ & $2.15 \pm 0.86$ & $2.19 \pm 0.85$ & $4.4 \pm 1.1$ & 0.081 \\
\hline $\begin{array}{l}\text { Number } \\
\text { of IUI } \\
\text { attempts }\end{array}$ & $1.86 \pm 0.71$ & $1.82 \pm 0.70$ & $3.68 \pm 0.89$ & 0.002 \\
\hline
\end{tabular}

\section{PREGNANCY RATE (\%)}

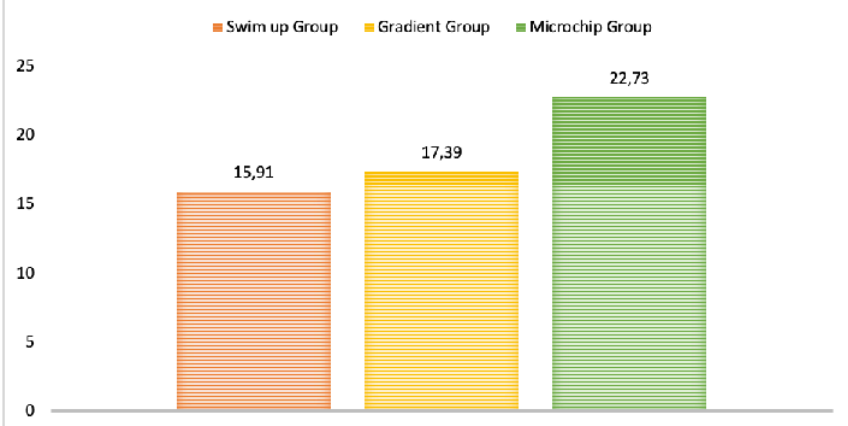

Figure 1. Pregnancy rates of the cases.

Table 2. Data of the cases related to follicular development, clinical course and pregnancy outcomes.

\begin{tabular}{|c|c|c|c|c|}
\hline & $\begin{array}{l}\text { Swim-Up } \\
\text { Group (n: } \\
44)\end{array}$ & $\begin{array}{l}\text { Gradient } \\
\text { Group (n: } \\
46)\end{array}$ & $\begin{array}{l}\text { Microchip } \\
\text { Group (n: } \\
22)\end{array}$ & $P$ \\
\hline $\begin{array}{l}\text { Dominant follicle } \\
\text { count formed with } \\
\text { induction }\end{array}$ & $1.52 \pm 0.52$ & $1.50 \pm 0.50$ & $1.50 \pm 0.51$ & 0.954 \\
\hline $\begin{array}{l}\text { Endometrium } \\
\text { thickness during } \\
\text { IUI }\end{array}$ & $10.68 \pm 1.21$ & $10.56 \pm 1.12$ & $10.90 \pm 1.19$ & 0.966 \\
\hline $\begin{array}{l}\text { Total motile sperm } \\
\text { count before } \\
\text { preparation }\end{array}$ & $\begin{array}{l}54 \times 106 \pm \\
36 \times 106\end{array}$ & $\begin{array}{l}57 \times 106 \pm \\
28 \times 106\end{array}$ & $\begin{array}{l}58 \times 106 \pm \\
25 \times 106\end{array}$ & 0.876 \\
\hline $\begin{array}{l}\text { Normal } \\
\text { Morphology } \\
\text { (Kruger) (\%) }\end{array}$ & $3.29 \pm 1.24$ & $3.0 \pm 1.23$ & $3.23 \pm 1.17$ & 0.782 \\
\hline $\begin{array}{l}\text { Motility rate after } \\
\text { preparation (\%) }\end{array}$ & $98 \pm 1.1$ & $93 \pm 3.23$ & $88 \pm 4.91$ & 0.875 \\
\hline $\begin{array}{l}\text { Number of sperm } \\
\text { inseminated after } \\
\text { preparation }\end{array}$ & $\begin{array}{l}23 \times 106 \pm \\
13.16 \times 106\end{array}$ & $\begin{array}{l}22 \times 106 \pm \\
11.89 \times 106\end{array}$ & $\begin{array}{l}19.18 \times 106 \pm \\
7.22 \times 106\end{array}$ & 0.819 \\
\hline Pregnancy rate (\%) & 15.91 & 17.39 & 22.73 & 0.064 \\
\hline
\end{tabular}




\section{DISCUSSION}

A total of 112 infertile patients treated with IUI in our center were evaluated in respect to pregnancy. The semen samples of patients with no chronic disease and no female or male factor during IUI treatment, were examined according to the manner of preparation. The most commonly used methods in IUI preparation are the Gradient and Swim-Up methods. The Microchip is a new sperm washing method used in IUI and IVF treatment [6].

When all the cases in the study were evaluated demographically, no significant difference was found. A difference was determined in respect of the IUI attempts $(p=0.002)$. Compared to the Swim-Up and Gradient groups, the number of IUI attempts in the Microchip group was statistically significantly high $(p=0.002)$. As the cost of the Microchip method is high and the State does not reimburse it, this method is not usually applied to patients planned to undergo IUI for the first time but is preferred for patients who have had several failed IUI attempts. However, even in the cases with relatively poor response in the cycles prepared by other washing methods, the pregnancy rate of $22.73 \%$ of the Microchip method is promising. When used in the first cycle, it is possible to reach higher pregnancy rates.

Previous studies that have compared sperm selection methods in IUI cases have focused on the Gradient and Swim-Up methods. Dodson et al. [8] examined the effect of these methods and reported that there was no significant difference in respect of sperm concentration and motility and pregnancy rates, and it was concluded that there was no superiority of one method over the other. Those results were similar to the findings of the current study. In contrast Depypere et al. [9] compared IUI methods in 117 cases and reported that the Gradient method was better than the SwimUp method, in respect to both sperm parameters obtained after washing and pregnancy rates. In a prospective, randomized, controlled study by Posada et al. in 2005 , the semen parameters and pregnancy outcomes of 82 patients were compared according to IUI preparation methods. Both before and after washing, the sperm parameters and the associated pregnancy rates were found to be significantly higher in the Swim-Up group than in the Gradient group [10]. In a review by Boomsa et al. in the Cochrane database which compared all methods except Microchip in 2011, none of the methods were found to have any significant effect on pregnancy and abortus [2]. One of the important studies related to sperm selection methods in assistive reproduction techniques was published by Sakkas et al. [11] in 2000 in Human Reproduction. In that study, the Swim-Up method was compared with the Gradient method in two different media (PureSperm and Percoll). The best method of sperm selection with the least nuclear DNA damage was investigated and it was concluded that both Gradient methods were more successful than the Swim-Up technique in the selection of sperm with less DNA damage [11].

In a well-designed study published in 2009, the presence of apoptotic and necrotic sperm was investigated with flow cytometry analysis after sperm preparation with the Swim-Up, and Gradient methods. The results of the study showed that both methods were successful in the selection of normal sperm. However, it was reported that healthier sperm could be selected quantitatively in the Gradient method and qualitatively in the SwimUp method, and the appropriate method could be selected according to the treatment to be applied (IUI or IVF) [12].

As centrifugation is applied in Gradient methods, impairments in the sperm DNA structure are seen more often as a result of an increase in reactive oxygen products [13]. Consequently, microfluid channel systems (Microchip) were developed for the selection of sperm with less DNA damage. This system is a chip with microchannels that mimic the microenvironment of the cervix and vagina. Sperm obtained with this method can be used in both IVF and IUI.

Although there are only a few studies in the literature that have compared the success of other sperm preparation methods with microfluid systems, studies have shown that microfluid systems could be useful in the selection of better sperm. In a 2011 study by Zhang et al., it was suggested that when the negative aspects of other traditional sperm selection methods were taken into consideration, the microfluid system was a better method because of ease-of-use 
and reliability [14]. It was also determined that the sperm obtained with this technique had significantly fewer radical oxygen products and less DNA fragmentation compared to the SwimUp method $[13,14]$. There was found to be a single retrospective cohort study in literature, which was recently published with a similar design to that of the current study, which compared microfluid systems with other sperm preparation methods in IUI cycles. In that study, 133 IUI cases using sperm prepared with the microfluid system were compared with 132 cases with sperm prepared with the gradient method. The pregnancy rates were determined as $18.04 \%$ in the microfluid group and $15.15 \%$ in the density gradient group, and the difference was not found to be statistically significant. When the ongoing pregnancy rates were compared, the rate was determined as $15.03 \%$ in the microfluid group and $9.09 \%$ in the gradient group. This difference was determined to be statistically significant. In conclusion the authors emphasized that the use of the microfluid method could significantly increase the ongoing pregnancy rate [15]. The results of our study can be considered to be of value as although there are other studies in literature with as high a number of cases, this is the first study to have compared the microfluid system with the two most frequently used sperm preparation methods.

Limitations of this study could be considered to be the retrospective design and the low number of Microchip cases.

Conclusion: Although there was no apparent difference between the traditional methods of Swim-Up and Gradient used in sperm preparation in IUI cycles, the sperm selection method with Microchip is being used increasingly and seems to be a promising alternative. There is a need for more extensive, prospective, randomized studies, which would include pregnancy outcomes.

Funding sources: There is no source of funding or financial interest in this study.

Conflict of Interest: The author has no conflict of interest related to this article.

\section{REFERENCES}

Ricci G, Perticarari S, Boscolo R, Montico M, Guaschino S, Presani G. Semen preparation methods and sperm apoptosis: swim-up versus gradient-density centrifugation technique. Fertil Steril. 2009;91(2):632-8.

2. Boomsma $\mathrm{CM}$, Cohlen BJ, Farquhar $\mathrm{C}$. Semen preparation techniques for intrauterine insemination. Cochrane Database Syst Rev. 2019 Oct 15;10:CD004507. doi: 10.1002/14651858.CD004507.pub4.

3. Wainer R, Albert M, Dorion A, Bailly M, Bergere M, Lombroso R, Gombault M, Selva $\mathrm{J}$. Influence of the number of motile spermatozoa inseminated and of their morphology on the success of intrauterine insemination Hum Reprod. 2004;19(9):2060-5. DOI:10.1093/humrep/deh390.

4. Berg U, Brucker C, Berg FD. Effect of motile sperm count after swim-up on outcome of intrauterine insemination. Fertil Steril 1997;67(4):747-750. DOI: 10.1016/s00150282(97)81377-5.

5. Horvath PM, Bohrer M, Shelden RM, Kemmann E. The relationship of sperm parameters to cycle fecundity in superovulated women undergoing intrauterine insemination. Fertil Steril 1989;52(2):288-94. DOI:10.1016/s0015-0282(16)60857-9.

6. Samuel R, Feng $H$, Jafek A, Despain D, Jenkins T, Gale B. Microfluidic-based sperm sorting \& analysis for treatment of male infertility. Transl Androl Urol. 2018;7(Suppl 3):S336-S347. DOI:10.21037/tau.2018.05.08.

7. Yetkinel S, Kilicdag EB, Aytac PC, Haydardedeoglu B, Simsek E, Cok T. Effects of the microfluidic chip technique in sperm selection for intracytoplasmic sperm injection for unexplained infertility: a prospective, randomized controlled trial. J Assist Reprod Genet. 2019;36(3):403-9. DOI:10.1007/s10815-018-1375-2.

8. Dodson WC, Moessner J, Miller J, Legro RS, Gnatuk CL. A randomized comparison of the methods of sperm preparation for intrauterine insemination. Fertil Steril. 1998;70(3):574-5. DOI:10.1016/s0015-0282(98)00210-6.

9. Depypere H, Milingos S, Comhaire F. Intrauterine insemination in male subfertility: a comparative study of sperm preparation using a commercial Percoll kit and conventional sperm wash. Eur J Obstet Gynecol Reprod Biol. 1995;62(2):225-9. DOI:10.1016/0301-2115(95)02196-e.

10. Posada MN, Azuero AM, Arango AM, Raigosa GC, Cano JF, Perez AL. Sperm washing with swim-up versus gradients in intra uterine insemination (IUI): results of a prospective randomized study comparing pregnancy rates and costs. Fertility and Sterility Abstract book 61st ASRM meeting. 2005; Vol. 84 Suppl 1:361.

11. Sakkas D, Manicardi GC, Tomlinson M, Mandrioli M, Bizzaro D, Bianchi PG, Bianchi $U$. The use of two density gradient centrifugation techniques and the swim-up method to separate spermatozoa with chromatin and nuclear DNA anomalies. Reprod. 2000 May:15(5):1112-6. do: 10.1093/humrep/15.5.1112.

Ricci G, Perticarari S, Boscolo R, Montico M, Guaschino S, Presani G. Semen preparation methods and sperm apoptosis: swim-up versus gradient density centrifugation technique. Fertit Steril. 2009:91(2):632-8. DOl:10.1016/jferthstert 2007 11.068.

13. Aitken RJ., Clarkson JS. Significance of reactive oxygen species and antioxidants in defining the efficacy of sperm preparation techniques. J. Androl. 1988;9(6):367-

14. Zhang X, Khimji I, Gurkan UA, Safaee H, Catalano PN, Keles HO, Kayaalp E, Demirci U. Lensless imaging for simultaneous microfluidic sperm monitoring and sorting. Lab Chip. 2011;11(15):2535-40. DOI:10.1039/c1lc20236g.

15. Gode F, Bodur T, Gunturkun F, Gurbuz AS, Tamer B, Pala I, Isik AZ. Comparison of microfluid sperm sorting chip and density gradient methods for use in intrauterine insemination cycles. Fertil Steril. 2019;112(5):842-848.e1. doi:10.1016/j. fertnstert.2019.06.037 